\title{
Prolonged Elevation of Insulin Content in the Unicellular Tetrahymena After Insulin Treatment: Induction of Insulin Production or Storage?
}

\author{
GYÖRGY CSABA ${ }^{1 *}$, ANNAMÁRIA GAÁL ${ }^{1}$, PÉTER KOVÁCS ${ }^{1}$, GYÖRGY SIMON ${ }^{2}$ \\ AND LÁSZLÓ KÖHIDAI ${ }^{1}$ \\ ${ }^{1}$ Department of Genetics, Cell and Immunobiology, Semmelweis University of Medicine, H-1445 Budapest \\ $P O B$ 370, Hungary \\ ${ }^{2}$ Department of Oral Biology, Semmelweis University of Medicine, H-1445 Budapest, POB 370, Hungary
}

\begin{abstract}
In the unicellular organism, Tetrahymena, the first encounter with an exogeneously given hormone results in hormonal imprinting. This causes an increase of the binding capacity of receptors and the production of the appropriate hormone in the progeny generations of the treated cell. In the present experiments the quantity (using radioimmunoassay) and localization (using confocal laser scanning microscopy) of the immunologically insulin-like material (hereafter insulin) were studied for 10 days after $4 \mathrm{~h}$ or $24 \mathrm{~h} 10^{-6} \mathrm{M}$ insulin treatment (hormonal imprinting). Forty-eight hours after both insulin treatments a high quantity of insulin was present in the cells. This value was also significantly increased after $96 \mathrm{~h}$. After 8 days the difference to the control was significant only in the $24 \mathrm{~h}$ treated group. Confocal microscopy (using antibody to pig insulin) localized insulin in the cell body. The oral field contained extremely high quantities of the endogeneous hormone. Insulin treatment (after 48 and $96 \mathrm{~h}$ ) caused an elevation of insulin content in general, and specific accumulation in the posterior sections of the cell, around the nucleus and in the periphery were observed. Ten days after both treatments only the peripheral region of the cell body and the ciliary row contained more insulin than the control. This means that after insulin treatment the quantity of insulin increases for a lengthy time period which is followed by the expression of insulin in the peripheral region. Insulin contained by Tetrahymena $48 \mathrm{~h}$ after imprinting stimulated glucose uptake of rat diaphragm. Copyright (C) 1999 John Wiley \& Sons, Ltd.
\end{abstract}

KEY WORDS - Tetrahymena pyriformis; insulin production; insulin storage; hormonal imprinting; receptor; insulin localization

\section{INTRODUCTION}

The unicellular Tetrahymena produces hormone receptors, ${ }^{1-5}$ hormones ${ }^{6-9}$ and second messengers $^{10-13}$ characteristic of higher animals. These molecules are interrelated, and influence each other. The exogeneously given hormones of higher animals can be bound by the receptors of Tetrahymena causing second messenger activation and evoking a response by the cell. At the first

\footnotetext{
* Correspondence to: G. Csaba, Department of Genetics, Cell and Immunobiology, Semmelweis University of Medicine, H-1445 Budapest, POB 370, Hungary.

Contract grant sponsor: National Research Fund, Hungary. Contract grants no: (OTKA) T-024064, T-22754.

encounter of the hormone and the appropriate receptor, a hormonal imprinting develops which specifies the receptor, usually increasing its binding capacity and amplifying the response of the cell. ${ }^{1,3,14-16}$ The effect of imprinting is transmitted to hundreds of progeny generations and helps the cells in the sophisticated recognition of molecules and in the differentiation between noxious and advantageous materials.

Insulin is one of the hormones produced by Tetrahymena, ${ }^{6}$ as well as being recognized by its receptors. ${ }^{17}$ Exogeneously administered insulin promotes glucose uptake by the cell ${ }^{18}$ and increases its cell division capacity. ${ }^{19}$ This is similar to that seen in higher animals. Insulin was also found in the ciliary membrane of Tetrahymena. ${ }^{16}$ In an earlier experiment ${ }^{20}$ we determined the presence of 
insulin after insulin treatment (imprinting) and a long-lasting (21 days, about 200 generations) increase was observed using an immunocytochemical method. However, we could not determine by this method the exact quantity of insulin and where the insulin became localized: i.e., is it present as a component in the plasma membrane, or is it accumulated in the body of the cell as a product? In the present experiments radioimmunossay and confocal microscopy were used for determining the exact quantity and localization of insulin after single short and long insulin treatments. The insulin-like effect of the content of the Tetrahymena was also studied.

\section{MATERIALS AND METHODS}

\section{Cells and Culturing}

Tetrahymena pyriformis GL strain was used in the logarithmic phase of growth. The cells were cultured at $28^{\circ} \mathrm{C}$ in tryptone medium (Sigma, St Louis, USA) containing $0 \cdot 1$ per cent yeast extract. The density of Tetrahymena cultures studied was $10^{4}$ cell $\mathrm{ml}^{-1}$.

\section{Treatment of Cultures and Collection of Samples}

Cultures were treated with $10^{-6} \mathrm{M} \quad(0 \cdot 144$ $\mathrm{IU} \mathrm{m}{ }^{-1}$ ) insulin (Actrapid MC, Novo, Denmark) for 4 and $24 \mathrm{~h}$. In the control groups the solvent of the hormone was added. After treatment the cells were transferred to fresh medium. Cells of each group were consecutively transferred into fresh medium on every second day. Samples were taken at 48 and $96 \mathrm{~h}$, and 8 and 10 days after the insulin treatment. Cells and supernatant were separated by centrifugation. Subfractions containing the cells were sonicated (Vibra-Cell, Danbury, USA), 15 cycles per $3 \mathrm{ml}$ sample $\left(2 \times 10^{6}\right.$ cell ml $^{-1}$ in PBS and $20 \mathrm{mU}$ aprotinin).

\section{Determination of Insulin by Radioimmunoassay (RIA)}

For the determination of insulin ${ }^{125}$ I-insulin RIA was used (Izinta, Hungary; RIA-kit for direct quantitative determination of human insulin). The standard was suitable for the determination of concentration ranges between $1.25 \mu \mathrm{U} \mathrm{ml}^{-1}$ to $160 \mu \mathrm{U} \mathrm{ml}^{-1}$, so we could measure only between these values. The measurements were repeated seven times (two parallels each). Estimation of significance was done using the Student's t-test.

\section{Immunocytochemical Localization of Insulin-like Material}

Populations of Tetrahymena cultivated in the manner above were treated with $10^{-6} \mathrm{M}$ insulin (Semilente MC, Novo, Copenhagen, Denmark) for $1 \mathrm{~h}$ or $24 \mathrm{~h}$. The control Tetrahymena did not take up insulin. After washings, the cells were further cultivated for 10 days; at two, four and 10 days, samples of cells were fixed with 4 per cent paraformaldehyde solution (dissolved in $\mathrm{pH} 7.2$ PBS) for $5 \mathrm{~min}$, and then washed twice in wash buffer $(0.1$ per cent BSA; $20 \mathrm{~mm}$ Tris- $\mathrm{HCl} ; 0.9$ per cent $\mathrm{NaCl} ; 0.05$ per cent Tween 20; pH 8.2). To block non-specific binding of antibodies the cells were treated with blocking buffer (1 per cent BSA in PBS) for $30 \mathrm{~min}$ at room temperature. Aliquots from cell suspensions $(50 \mu \mathrm{l})$ were transferred into Eppendorf microfuge tubes, and $50 \mu \mathrm{l}$ primary antibody (anti-pig insulin, developed in guinea pig; Sigma, St Louis, USA; dilution 1:200 in antibody buffer [ 1 per cent BSA in wash buffer]) was added for $45 \mathrm{~min}$ at room temperature. Negative controls were carried out with $50 \mu \mathrm{l}$ PBS containing $10 \mathrm{mg} \mathrm{ml}^{-1}$ BSA instead of primary antibody.

After washing four times with wash buffer to remove excess primary antibody the cells were incubated with secondary antibody (FITC-labelled monoclonal anti-guinea pig $\operatorname{IgG}$ developed in mouse; Sigma, St Louis, USA; dilution 1:50 with antibody buffer) for $30 \mathrm{~min}$ at room temperature. After washings with wash buffer four more times the cells were mounted onto microscopic slides.

The labelled and mounted cells were analysed in a BioRad MRC 1024 confocal laser scanning microscope equipped with a krypton-argon mixed gas laser as a light source. Excitation was carried out with the $480 \mathrm{~nm}$ line from the laser.

\section{Study of Glucose Uptake Under the Effect of the Tetrahymena Content}

Cultures were treated with $10^{-6} \mathrm{M}$ insulin (Actrapid MC, Novo, Denmark) for $60 \mathrm{~min}$. After treatment the cells were transferred into flasks containing fresh culture medium. The cultures were maintained at $48 \mathrm{~h}$ at $28^{\circ} \mathrm{C}$, then the cells were isolated from the cultures by centrifugation. The 
procedure was the same for the controls, except for insulin treatment.

Female Wistar rats (about $250 \mathrm{~g}$ body weight, kept on normal rat chow ad libitum) were exsanguinated in light ether anaesthesia. Diaphragms were removed and rinsed in ice-cold Krebs-Ringer bicarbonate solution (KRB) and then dissected into two parts. Then, while in cooled tubes their weights were measured. KRB-glucose $(3.0 \mathrm{ml})$ was added into incubation tubes (glucose concentration $500 \mathrm{mg}^{-1}$ ) and into each tube a half diaphragm was placed. ${ }^{21}$ The diaphragms were gassed with carbogen at $4^{\circ} \mathrm{C}$. Tetrahymena $(0.5 \mathrm{ml})$ suspension $\left(5 \times 10^{5}\right.$ cells $)$ was then ultrasonicated in the presence of $100 \mathrm{mU}$ aprotinin (Sigma, USA) $+10 \mu \mathrm{U}$ Gordox (Richter, Budapest, Hungary) in KRB-glucose. The tubes were placed into a $37^{\circ} \mathrm{C}$ shaking thermostat and $1 \mathrm{kBq}$ labelled glucose (D-[2- $\left.{ }^{3} \mathrm{H}\right] /$ glucose; Amersham, Buckinghamshire, UK; $625 \mathrm{Gbq} \mathrm{mmole}^{-1}$ diluted by distilled water) was added. Simultaneously 10 tubes were used and to ensure an equal gas flow, a peristaltic pump was employed. After $60 \mathrm{~min}$ the diaphragms were washed rapidly in ice-cold $\mathrm{KRB}$ and homogenised in $3.0 \mathrm{ml}$ distilled water in an Ultra-Turrax homogeniser for $2 \times 20 \mathrm{~s}$. The suspension was added to Ultima-Gold cocktail (Packard, USA) and measured in a Beckman liquid-scintillation spectrometer. The half-diaphragms expressed to Tetrahymena homogenate were compared always with the other half of diaphragms in KRB-glucose. For statistical evaluation the Student t-test was used.

\section{RESULTS}

\section{Insulin Radioimmunossay}

The exact quantities of insulin were studied in Tetrahymena after short (4 h) and long (24 h) insulin treatment. In the control (untreated) cells a measurable quantity of insulin was present. At $48 \mathrm{~h}$ following the short treatment, an enormous quantity of insulin was detected in the cells. The measuring capacity of the RIA was limited $(160 \mu \mathrm{lU})$, however the cellular value was at the maximum possible level. After $96 \mathrm{~h}$ the quantity of insulin had fallen to half of the $48 \mathrm{~h}$ values, but this was still $12 \times$ greater than the control. After eight days there was no difference compared with the control (Figure 1.)

Forty-eight hours after the long treatment an $11 \mathrm{x}$ increase in the quantity of insulin was present in the treated cells compared with the control cells. After four days this difference was about $3 \times$, while after 8 days a small, however still significant, elevation was observed. After 10 days there was no difference between the control and treated cells at all (Figure 2).

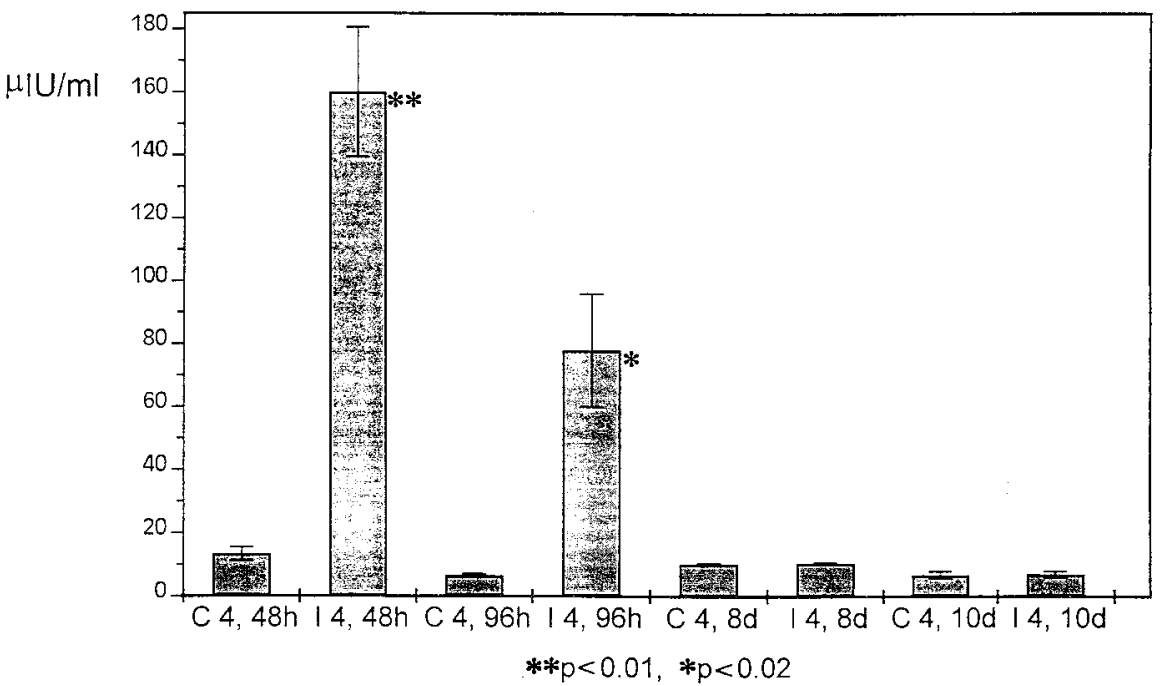

Figure 1. Quantity of RIA-detectable insulin in Tetrahymena homogenates of the control and $4 \mathrm{~h}$ insulin treated groups at different time points after treatment. $\mathrm{C}=$ control; $\mathrm{I}=$ insulin treated. Number 4 points to the duration of insulin treatment in hours. 


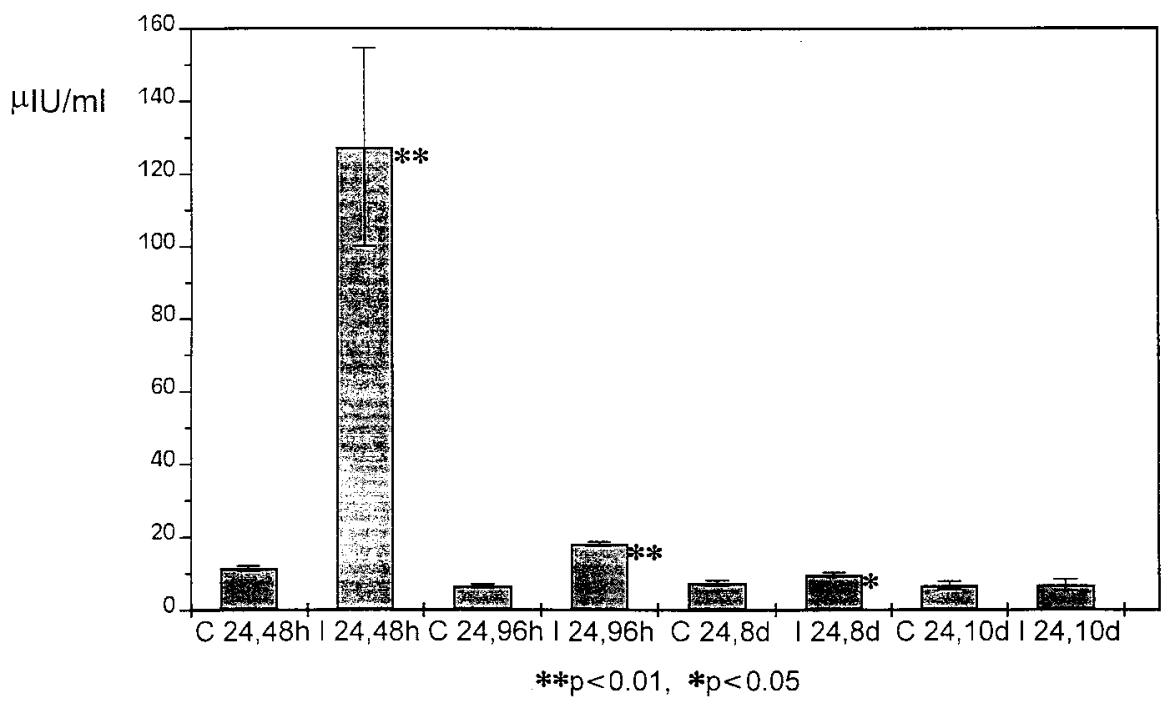

Figure 2. Quantity of RIA-detectable insulin in Tetrahymena homogenates of the control and $24 \mathrm{~h}$ insulin treated groups at different time points after treatment. $\mathrm{C}=$ control; $\mathrm{I}=$ insulin treated. Number 24 points to the duration of insulin treatment in hours.

\section{Confocal Microscopy}

In the control experiment, where first antibody (to insulin) was omitted, some bright patches were observed in the body of the cell. However, the periphery was absolutely free of fluorescence. Using both antibodies, more fluorescence was observed in the cell body and the periphery was bright, thus demonstrating the presence of insulin. In addition, the oral field also contained a high quantity of insulin (Figure 3). Two and four days after $4 \mathrm{~h}$ insulin treatment the quantity of insulin was increased. A higher quantity of insulin was attached to the nucleus and localized in the posterior part of the Tetrahymena as well as in the oral field (Figure 4). After 10 days this quantity was diminished in the main body of the organism but the intensity remained unchanged in the periphery of the cells (epiplasm and oral field).

Two and four days after $24 \mathrm{~h}$ treatment, an enormous quantity of insulin fluorescence was observed in the bottom of the cells, around the nucleus and in the periphery (Figure 5). After 10 days, the quantity of insulin in the body was reduced, in contrast to the periphery, where the fluorescence was still well expressed and where it appeared also in the ciliary rows.

\section{Glucose Uptake by Diaphragm}

The homogenates of control Tetrahymena cells did not influence significantly the glucose uptake of diaphragm, compared with the glucose uptake of untreated diaphragm. However, there was a significant increase in glucose uptake using homogenates originating from insulin treated Tetrahymena (Figure 6).

\section{DISCUSSION}

The results demonstrate that insulin treatment intensively and durably influences the RIA-detectable insulin content of Tetrahymena. The effect of short treatment is more intense; the effect of long treatment is more durable. However, in both cases, the quantity of insulin reached a peak and then gradually decreased in the progeny generations and the difference between the control and treated cells disappeared by the 10th day. So it is not possible to distinguish between what was due to imprinting and what to the presence and decomposition of the imprinter (insulin) in the cell.

In mammalian cells the receptor-bound insulin is internalized and digested in the endosomes. ${ }^{22}$ In this digestion, different protease enzymes take part. ${ }^{23}$ In the liver and some other organs, however, a specific insulin protease is present. ${ }^{24-26}$ Tetrahymena contain multiple forms of proteolytic enzymes, among which are different acid proteases, e.g. cathepsin $B,{ }^{27-30}$ which can split insulin. These enzymes are also secreted into the extracellular medium without any modification. ${ }^{31}$ Protein digestion occurs in Tetrahymena over broad ranges of 

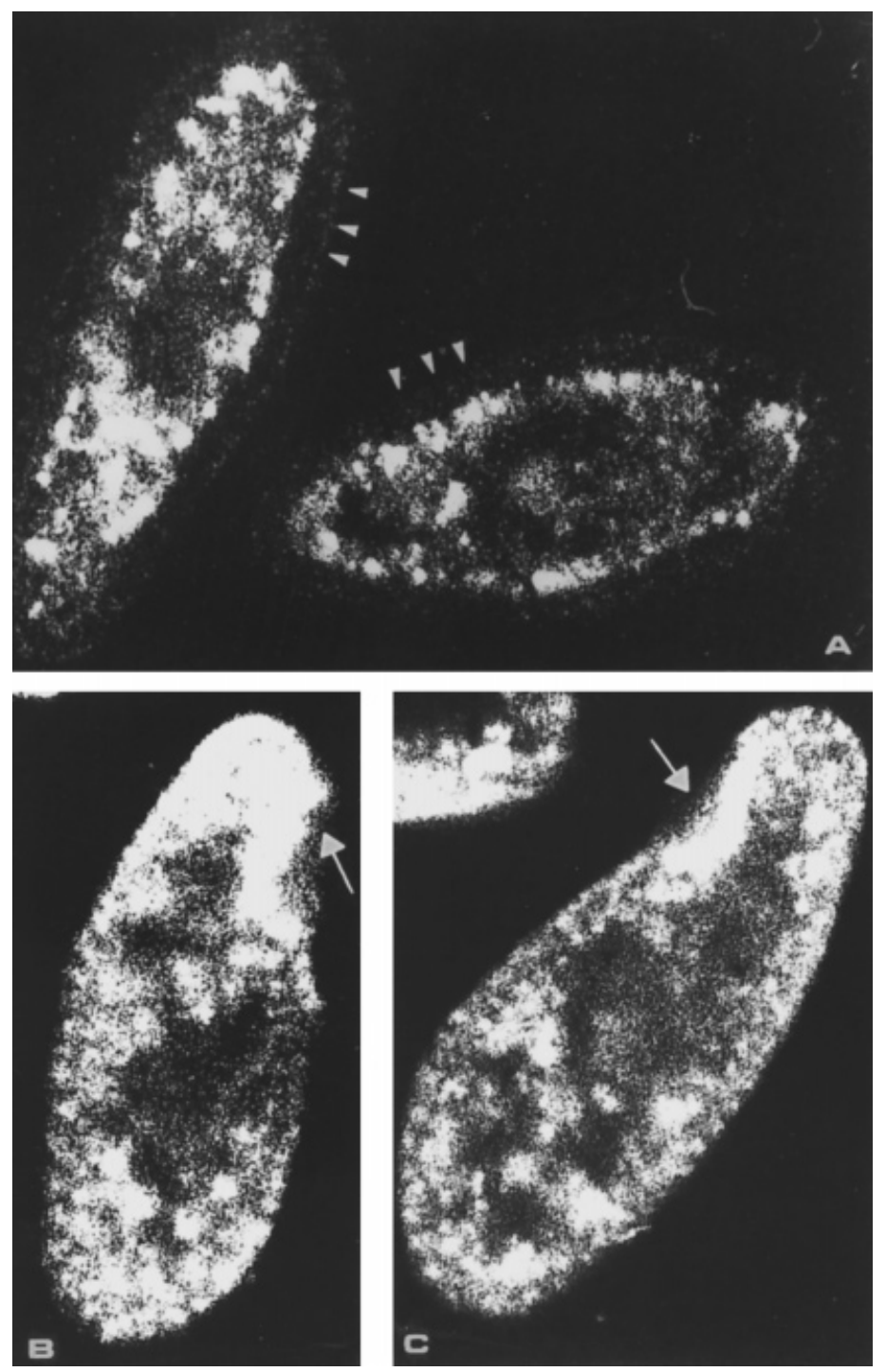

Figure 3. Confocal microscopic analysis. $\mathrm{a}=$ absolute control (without using first antibody) $1400 \times$; $\mathrm{b}$ and $\mathrm{c}=$ control (untreated, $1800 \times$ ) Tetrahymena. Arrowheads point to the peripheral area, which is free of fluorescence; arrows indicate oral field.

$\mathrm{pH},{ }^{27}$ and with regard to protein digestion, the cell reacts in much the same way as mammalian cells. ${ }^{32}$ This allows us to suppose that insulin present in the medium can be digested both extra- and intracellularly. Two hours after insulin treatment in rat fibroblasts only about 30 per cent of the internalized hormone remains intact. ${ }^{33}$ It seems difficult to imagine therefore that after four or eight days those insulin molecules that were detected were those given during treatment, considering particularly that during the elapsed time the medium was changed many times and the 80th generation was studied in the 8th day. In addition, lower insulin concentrations were observed after long treatment, although this could provide a prolonged possibility of insulin uptake. This makes it likely that insulin production was induced by the imprinting; peaking $48 \mathrm{~h}$ after treatment and then decreasing. Nevertheless, in a previous experiment, ${ }^{21}$ immunocytochemistry demonstrated that insulin levels were elevated after 21 days with no gradual decrease, relative to the control. This controversy stimulated us to study the localization of insulin after insulin imprinting. 

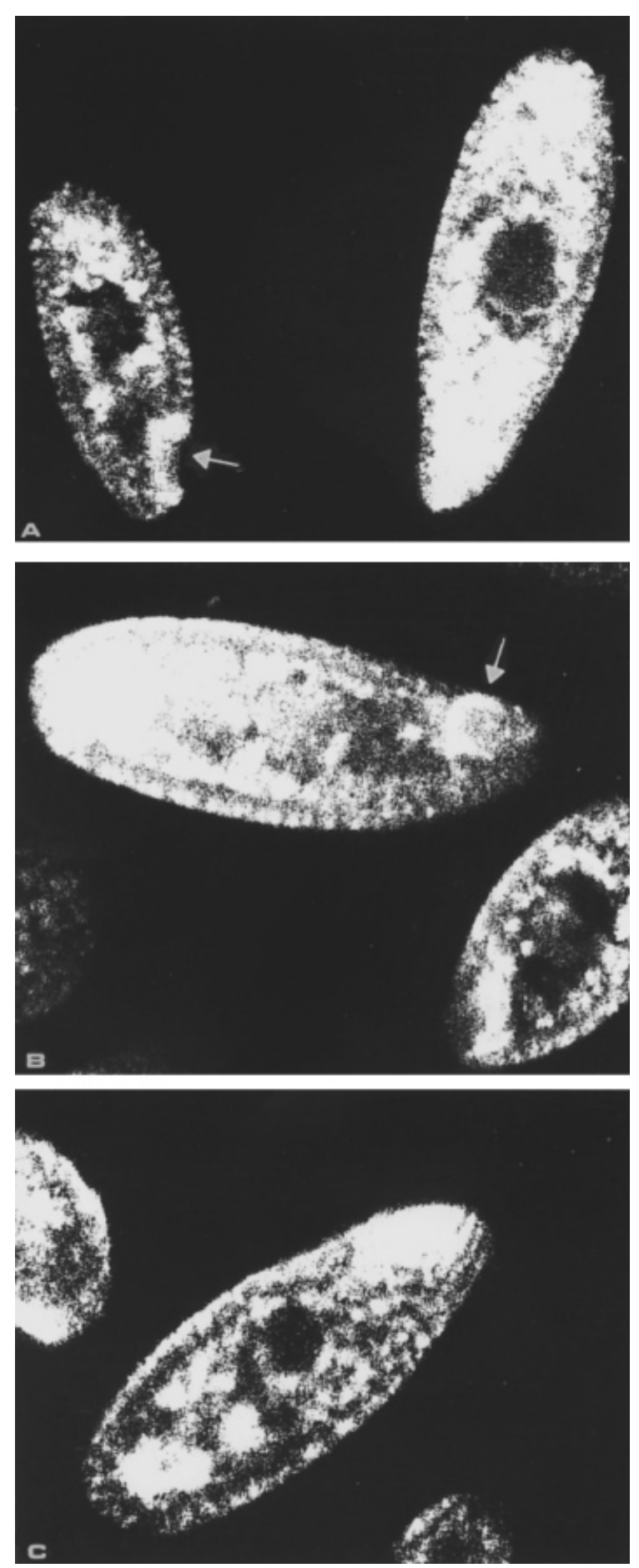

Figure 4. Confocal microscopic analysis of Tetrahymena treated with $10^{-6} \mathrm{M}$ insulin for $4 \mathrm{~h}$. a = after $48 \mathrm{~h}, 1600 \times$; $\mathrm{b}=$ after $96 \mathrm{~h}, 1800 \times ; \mathrm{c}=$ after 10 days, $1800 \times$. Arrows point to the oral field.
The confocal microscopic observations shed light on the differences between the present (RIA) and earlier (fluorimetric) experiments. Initially after insulin treatment (imprinting) the quantity of insulin increases inside the cells (cytoplasm and epiplasm). This is demonstrated by RIA as well as by cytological techniques. Later, when the insulin content (production and/or storage) of cells returns to normal levels, the elevated insulin concentration remains in the peripheral part of the cells (epiplasm, cilia). This differs from the controls and can be demonstrated only by cytological (fluorimetric and confocal) methods. This means that the elevation of insulin content in the cells after imprinting is shorter (four days after $4 \mathrm{~h}$ treatment and 8 days after $24 \mathrm{~h}$ treatment) than was believed earlier, however the enrichment of peripheral insulin by the imprinting seems to be correct. This insulin can be the hormone itself or a 62 $67 \mathrm{kDa}$ protein which is immunologically similar to insulin as demonstrated by Christopher and Sundermann. ${ }^{16}$ However, our experiments do not give any clear-cut answer on the question as to whether the higher insulin content of the cells was caused by induced insulin production or by the storage of insulin taken up from the environment.

The appearance of insulin in the oral region is interesting. The exogeneously given insulin is accumulated in the oral field as was demonstrated earlier. ${ }^{34}$ On the basis of the present experiment it cannot be decided, whether insulin produced or stored by the cell, or insulin secreted by the cell was bound to this region (autocrine regulation). At present, assumption of the binding of the exogeneously given insulin is excluded, considering that a bright insulin fluorescence was also observed in the oral region of the control (untreated) cells.

The material which was immunologically related to insulin also influenced glucose uptake by rat diaphragm (Figure 6). In the experiments of LeRoith et al. ${ }^{6}$ insulin produced by control (not insulin treated) Tetrahymena influenced the glucose uptake of adipose tissue. In our study diaphragm did not react significantly to the control Tetrahymena homogenate, however a significant elevation of glucose uptake was observed by treatment with the homogenate of Tetrahymena imprinted with insulin $48 \mathrm{~h}$ before. Comparing the sensitivity of the two methods (tissues), the difference is understandable. However, the sensitivity of the RIA for insulin is an order of magnitude greater than the in vitro bioassays ${ }^{35}$ and this can explain why the elevation of insulin 

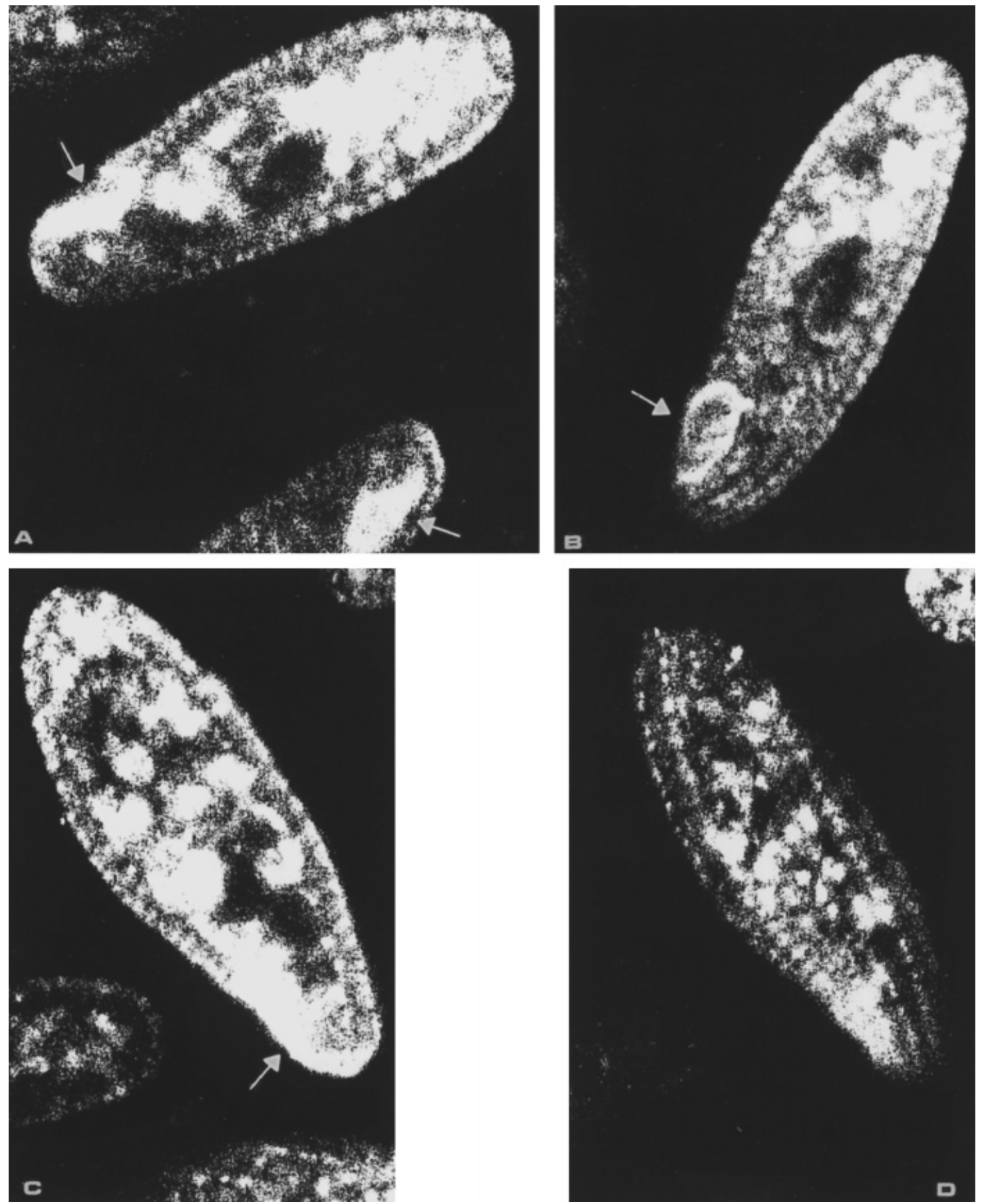

Figure 5. Confocal microscopic analysis of Tetrahymena treated with $10^{-6} \mathrm{M}$ insulin for $24 \mathrm{~h}$. a $=$ after $48 \mathrm{~h}, 1800 \times ; \mathrm{b}=$ after $96 \mathrm{~h}, 1800 \times ; \mathrm{c}$ and $\mathrm{d}=$ after 10 days, $1800 \times$. C shows mid-region of the cell body; D shows the surface of the cell. 


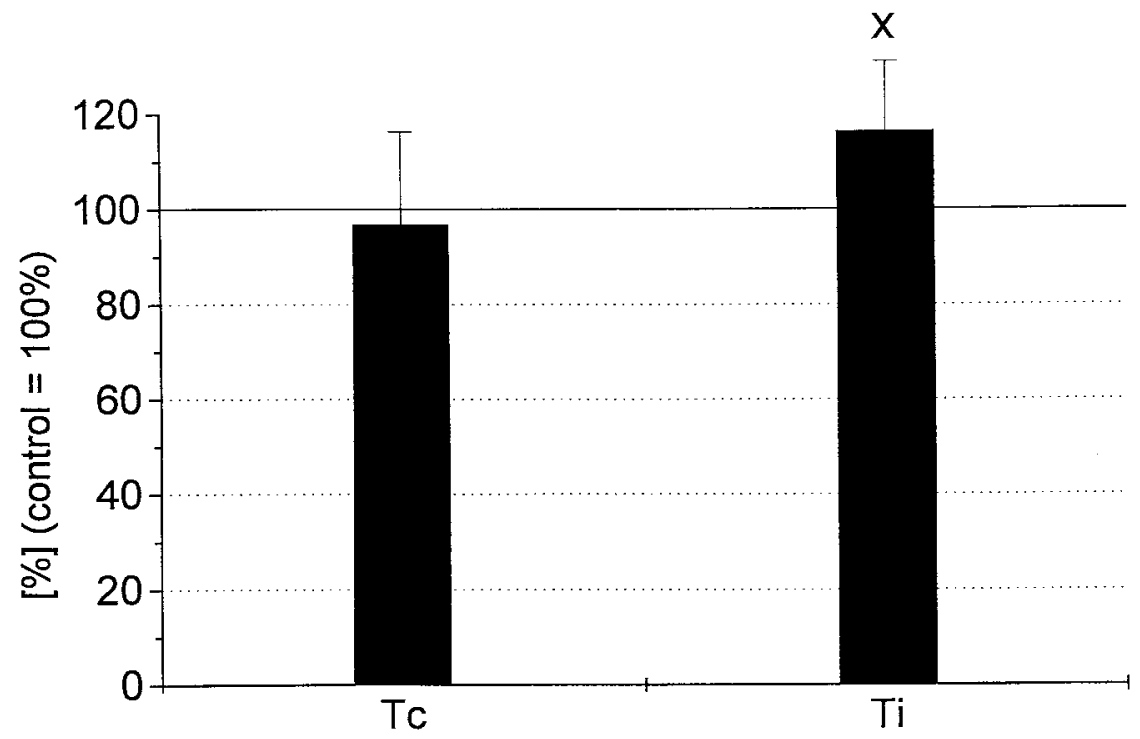

Figure 6. Glucose uptake of rat diaphragm treated with homogenates of control (Tc) and insulin imprinted (Ti) Tetrahymena, compared with the glucose uptake of diaphragms in KRB-glucose only, as 100 per cent.x $=p<0.05$.

content was higher using RIA at $48 \mathrm{~h}$ than the effect on glucose uptake monitored in the less sensitive diaphragm assay.

\section{REFERENCES}

1. Csaba, G. (1980). Phylogeny and ontogeny of hormone receptors: the selection theory of receptor formation and hormonal imprinting. Biol. Rev., 55, 47-63.

2. Csaba, G. (1981). Ontogeny and Phylogeny of Hormone Receptors. Karger: Basel, New York.

3. Csaba, G. (1985). The unicellular Tetrahymena as a model cell for receptor research. Int. Rev. Cytol., 95, 327-377.

4. O’Neil, J. B., Pert, C. B., Smith, C. C., Higgins, W. J. and Zipser, B. (1988). Identification and characterization of the opiate receptor in the ciliated protozoan Tetrahymena. Brain. Res., 450, 303-315.

5. Zipser, B., Ruff, M. R., Smith, C. C., Higgins, W. J. and Pert, C. B. (1988). The opiate receptor: a single $11 \mathrm{kDa}$ recognition molecule appears to be conserved in Tetrahymena, leech and rat. Brain. Res., 463, 296-304.

6. LeRoith, D., Schiloach, J., Roth, J. and Lesniak, M. A. (1980). Evolutionary origins of vertebrate hormones: substances similar to mammalian insulin are native to unicellular eukaryotes. Proc. Natl. Acad. Sci. U.S.A., 77, 6184-6186.

7. LeRoith, D., Liotta, A. H., Roth, J., Schiloach, J., Lewis, M. E., Pert, C. B. and Krieger, D. T. (1982). ACTH and beta endorphin-like materials are native to unicellular organisms. Proc. Natl. Acad. Sci. U.S.A., 79, 2086-2090.

8. LeRoith, D., Schiloach, J., Berelowitz, M., Frohman, L. A., Liotta, A. S., Krieger, D. T. and Roth, J. (1983). Are messenger molecules in microbes the ancestors of vertebrate hormones and tissue factors? Fed. Proc., 42, 2602-2607.
9. LeRoith, D., Roberts, C. Jr, Lesniak, M. A. and Roth, J. (1987). Receptor for intercellular messenger molecules in microbes: similarity to vertebrate receptors and possible implications for diseases in man. In: Development of Hormone Receptors. (Csaba, G., ed.). Birkhauser: Basel.

10. Kuno, T., Yoshida, N. and Tanaka, C. (1979). Immunocytochemical localization of cyclic AMP and cyclic GMP in synchronously dividing Tetrahymena. Acta Histochem. Cytochem., 12, 563.

11. Kovács, P. and Csaba, G. (1990). Involvement of phosphoinositol (PI) system in the mechanism of hormonal imprinting. Biochem. Biophys. Res. Commun., 170, 119-126.

12. Kovács, P. and Csaba, G. (1997). PLA activity in Tetrahymena pyriformis. Effects of inhibitors and stimulators. J. Lipid Med. Cell. Signalling, 15, 233-247.

13. Muto, Y., Kudo, S. and Nozawa, Y. (1983). Effect of local anesthetics on calmodulin dependent guanylate cyclase in the plasma membrane of Tetrahymena pyriformis. Biochem. Pharmacol., 32, 3559-3563.

14. Csaba, G. (1994). Phylogeny and ontogeny of chemical signalling: origin and development of hormone receptors. Int. Rev. Cytol., 155, 1-48.

15. Christopher, G. K. and Sundermann, C. A. (1992) Conventional and confocal microscopic studies of insulin receptor induction in Tetrahymena pyriformis. Exp. Cell. Res., 201, 477-484.

16. Christopher, G. K. and Sundermann, C. A. (1995). Isolation and partial characterization of the insulin binding sites of Tetrahymena pyriformis. Biochem. Biophys. Res. Commun., 212, 515-523.

17. Kovács, P. and Csaba, G. (1990). Evidence of the receptor nature of the binding sites induced in Tetrahymena by insulin treatment. A quantitative cytofluorimetric technique for the study of binding kinetics. Cell. Biochem. Funct., 8, 49-56.

18. Csaba, G. and Lantos, T. (1975). Effect of insulin on the glucose uptake in Protozoa. Experientia, 31, 107-109. 
19. Hegyesi, H. and Csaba, G. (1997). Time and concentrationdependence of the growth-promoting activity of insulin and histamine in Tetrahymena. Application of the MTTmethod for the determination of cell proliferation in a protozoan model. Cell Biol. Int., 21, 289-293.

20. Csaba, G. and Kovács, P. (1995). Insulin treatment (hormonal imprinting) increases the insulin production of the unicellular Tetrahymena long term. Is there a simultaneous formation of hormone receptor and hormone? Cell Biol. Int., 19, 1011-1014.

21. Lyngoe, J. (1965). Serum insulin. Acta Med. Scand., 179, 1-98. (Suppl.).

22. Duckworth, W. C., Hamel, F. G. and Peavy, D. E. (1988). Hepatic metabolism of insulin. Am. J. Med., 85, 71-76.

23. Neal, G. W. and Kitabchi, A. E. (1982). Insulin degradation by human skeletal muscle. Biochim. Biophys. Acta, 719, 259-266.

24. Poole, G. P., O'Connor, K. J., Lazarus, N. R. and Pogson, C. I. (1982). ${ }^{125}$ I-labelled insulin degradation by isolated rat hepatocytes: the roles of glutathione-insulin transhydrogenase and insulin-specific protease. Diabetologia, 23, 49-53.

25. Gammeltoft, S. (1984). Insulin receptors: binding kinetics and structure-function relationship of insulin. Physiol. Rev., 64, 1321-1378.

26. Duckworth, W. C., Hamel, F. G., Peavy, D. E., Liepnieks, J. J., Ryan, M. P., Hermodson, M. A. and Frank, B. H. (1988). Degradation products of insulin generated by hepatocytes and by insulin protease. J. Biol. Chem., 263, $1826-1833$.
27. Straus, J. W., Migaki, G. and Finch, M. T. (1992). An assessment of proteolytic enzymes in Tetrahymena thermophila. J. Protozool., 39, 655-662.

28. Blum, J. J. (1975). Effects of metabolites present during growth of Tetrahymena pyriformis on the subsequent secretion of lysosomal hydrolases. J. Cell Physiol., 86, 131-142.

29. Blum, J. J. (1976). Lysosomal hydrolase secretion by Tetrahymena: a comparison of several intralysosomal enzymes with the isoenzymes released into the medium. J. Cell Physiol., 89, 457-472.

30. Banno, Y., Yano, K. and Nozawa, Y. (1983). Purification and characterization of a secreted protease from Tetrahymena pyriformis. Eur. J. Biochem., 132, 563-568.

31. Banno, Y., Yano, K. and Nozawa, Y. (1982). Biochemical characterization of secreted proteases during growth in Tetrahymena pyriformis WH-14: comparison of extracellular with intracellular proteases. J. Protozool., 29, 91-98.

32. Jonassen, T. O. and Grinde, B. (1986). Proteolytic response to nutritional step-down in Tetrahymena. Exp. Cell Res., 163, 165-174

33. Zapf, A., Hsu, D. and Olefsky, J. M. (1994). Comparison of the intracellular itineraries of insulin-like growth factor and insulin and their receptors in Rat-1 fibroblasts. Endocrinology, 134, 2445-2452.

34. Fülöp, A. K. and Csaba, G. (1997). Accumulation of insulin-gold particles in the oral apparatus of Tetrahymena after insulin pretreatment (imprinting). Microbios, 90, $123-128$.

35. Larner, J. (1985). Insulin and oral hypoglycemic drugs; glucagon. In: The Pharmacological Basis of Therapeutics. (Goodman Gilman, A. et al., eds) MacMillan: New York. 